\title{
The Implementation of Scientific Approach in Teaching English Based on 2013 Curriculum at SMAN $12 \times 11$ Kayutanam
}

\author{
Rigasyahyana Gani ${ }^{1}$ and Havid $\mathrm{Ardi}^{2}$
}

\author{
${ }^{1}$ Universitas Negeri Padang, Padang, Indonesia $\triangle$ (e-mail)syahyanariga@gmail.com \\ ${ }^{2}$ Universitas Negeri Padang, Padang, Indonesia $\bowtie$ (e-mail) havid_@fbs.unp.ac.id
}

\begin{abstract}
The research was to find out the implementation in using scientific approach in teaching English. The research was conducted at SMAN 1 2x11 Kayutanam, Padang Pariaman. The research used descriptive method. The data were taken from observation.The observation was used to find out the teaching learning process done by the teacher in the classroom in using scientific approach in teaching English. The result was, there were only $36 \%$ of aspects in 2013 curriculum have been implemented in teaching. From findings showed that in pre-activity was $80 \%$, observing activities $60 \%$, questioning $3 \%$, experimenting $40 \%$, association $17 \%$, and communicating $37 \%$, and post activity $80 \%$ had been done by the teachers. In conclusion, the teacher still got many problems in using scientific approach in teaching, it was showed that the aspects of 2013 curriculum have not been implemented yet maximally. Therefore, they should learn more about 2013 curriculum.
\end{abstract}

Keywords: Scientific Approach, Teaching English, Curriculum, implementation

\section{INTRODUCTION}

Since academic year 2013/2014, the government has changed the curriculum into 2013 curriculum. 2013 curriculum has been implemented in some school in Indonesia as a pilot project. Through this curriculum, the government hopes the students will be productive, creative and innovative. According to Permendikbud no. 69 of 2013, the purpose of 2013 curriculum is prepare Indonesian people to have the ability to live as individuals and citizens who are faithful, productive, creative, innovative, and effective also able to contribute to nation and the world. 2013 curriculum is an improvement of the Education Unit Level Curriculum KTSP which basically is a change in mindset and teaching culture from the teaching ability of educators in carrying out the teaching and learning process. The 2013 curriculum has been implemented for seven years in some schools in Indonesia, but there is still pros and cons on its implementation until now. Even the implementation of 2013 curriculum is still being reviewed and evaluated. The implementation of 2013 curriculum has been running poorly for some teachers because few years ago some teachers used conventional teaching method and when 2013 curriculum, the teacher are require to implement the scientific approach.

2013 curriculum provides an approach in teaching as the demand of $21^{\text {st }}$ century, that is using scientific approach.The steps of learning in this approach includes five steps, observing, questioning, experimenting, associating, and communicating. Those steps must be applied in the teaching. Kemendikbud (2013) and Lazim (2014)

\section{Scientific Approach}

According to Lazim (2014:1), scientific approach is defined as a learning process designed in such way the students actively construct concepts, laws or principles through the stages of observing (to identify or find problems), formulate problems, submit or formulate hypotheses, collect data, draw conclusions and communicate concepts, laws or principles that are discovered. It means that, the scientific approach is one of technique that the teacher should do in order to make students active through scientific stages so that they can construct new knowledge.

In using scientific approach in teaching, both teachers and students usually find difficulties in applying this approach, there are so many problems that the teachers found in the reality of teaching. Based on the researcher's informal interview with some an English teachers, the researcher found that some of English teachers found some difficulties in their teaching in implementing 2013 curriculum, the teacher still used the conventional strategy, they still confused in applying the scientific approach in their teaching, they confused to use the learning method in 2013 curriculum, they also found the problems from the 
students because the students wasn't creative in the learning process, they wasn't familiar with this approach of that curriculum and the students were not ready to be independent students.

The steps of the scientific approach in teaching learning process includes the following step such as observing, questioning, associating, experimenting, and communicating by Majid (2014) and Kemdikbud (2013) can be explained as follows:

\section{a. Observing}

The observing method prioritizes the meaningfulness of the learning process. The advantage of observing methods is that students are happy and challenged and easy to implement. The teacher provides real objects and interesting way so students are interested in the object we are presenting. In this activity the teacher usually needs a lot of time, money and energy to prepare it.

In observing, teacher opens widely an opportunity to students to make an observation through activities: seeing, listening, and reading. The teacher facilitates students to make observations, trains them to pay attention (see, read, hear) important things from an object they are observed.

b. Questioning

In questioning, students need to be trained to formulate questions related to the topic being studied. Learning activities are very important to increase the curiosity of students and develop their abilities for lifelong learning. The teacher asks and motivate motivate students to ask questions related to an object they have observed before.

In questioning, the teacher opens wide opportunities to students to ask questions related what they have observed before. The students are asked to make a questions based on the material or subject the the teacher given to them. The teacher needs to guide students to be able to ask questions: questions about the results of observing concrete objects up to the abstraction with regard to facts, concepts, procedures, or other things that are more abstract.

c. Experimenting

In experimenting, students are asked to do an experiment. In doing an experiment, students collect as much information that they can collect. They can collect from any resources by reading other sources beside handbook. They also can collect the information by conducting the interview. The purpose of doing an experiment is to develop various learning objectives, namely attitudes, skills, and knowledge. In this activity, the students try to create an experiment based on the material given to them. They should have the capability in doing the experiment.

d. Associating

Associating is a term in the framework of the learning process with the scientific approach adopted in curriculum 2013 to illustrate that students are active actors. Reasoning is a logical and systematic process of thinking on observable empirical facts to get conclusion in the form of knowledge.
In this step, students process the information that they have collected before from their experimenting, observing and from gathering information activity.

e. Communicating

Communicating is the activity to tell the result of what have discussed before in experiment and associating. Here, students can communicate the results of their work arranged together in groups or individuals from the conclusions. This activity is to write down or tell what is found in activities to find information, associate and find patterns. Then, the results are presented and assessed by the teacher as a result of learning of students or groups of students.

In conclusion, there are some activities should be done in scientific approach such as observing, questioning, experimenting, associating and communicating for the purpose to make the student active, creative and innovative.

\section{Teaching English}

In teaching English, the teacher as a facilitator for their students to meet the target of education, the teacher should more productive, creative and innovative. So, as the teacher should have some planning and strategies for their student in their teaching. Before the teacher teach, they should prepare some preparation such as; making lesson plan, teaching implementation and evaluating.

According to Trowbridge and Bybee (1990:27) in Majid, before teacher start to teach the material, the teacher should make decisions in making lesson plan. The decisions that the teacher thinks before they teach in the class should be considered and think the answer by teacher carefully to create the actual condition so the teacher can achieve the purpose of the lesson.

Callum (2000) states that lesson plan is the detail description of teaching learning process conducted by teacher. It contains of very detail activity from preteaching, main and the closing phase as a partial of lesson plan documents. According to Permendikbud No 22 (2016) The Lesson Plan is a face-to-face learning activity plan for one or more meetings. Based on the theory above, it can be concluded that the lesson plan is a set plan of activities for one or more meetings to achieve a competency.

The second that the teacher decide in teaching is related to implement the lesson. According to Sudjana (1989:147) in Majid, he states the strategy in learning is the real action from the teacher in teaching by using certain ways that are considered more effective and efficient. In implement the lesson, there are some activities the teachers should be done according to Sudjana (19989:149) in Majid. (1) explain to the students the purpose of the lesson, (2) discuss the material, (3) gives the concrete examples for each material, (4) conclude the lesson.

Based on Lampiran permendikbud no 22 (2013), there are three steps of teaching. Pre-activity, whilst activity and post activity. 


\section{Pre-activity}

In Pre-activity, teacher prepare students' mentally and physically, motivate students, ask question to motivate them to the topic, tell them the purpose and basic competence will be achieved, and tell the scope of material based on the syllabus.

2. Whilst-teaching activity

In whilst activity, it should use learning models, learning methods, learning media, and learning resources that are tailored to the characteristic of students and subject.The choice of thematic, scientific, inquiry, discovery or project based learning approach is adjusted to the characteristic of competencies and levels of education. 3. Post-activity

In post activity, teacher and students conclude the lesson, doing an evaluation, give the feedback and result of learning, planning for remedial, enrichment programs, counseling services and / or giving assignments to both individual and group assignments according to the learning outcomes of students, and delivering learning plans for the next meeting.

While, Hosnan (2014) states that there are also three steps that the teacher should apply in their teaching based on 2013.

1. Pre-activity

In pre-activity, there are some activities that the teachers do in teaching learning process, prepares students' physically and mentally, asking a previous lesson, leads the students to the material given, tell the purpose of the lesson or basic competency will be achieved, tell the material and explain the activities based on the syllabus

2. Whilst-activity

In whilst activity, there are also some activities the teachers do in teaching learning process. They are based on the following steps based on the scientific approach.

a. Observing

In observing, there are some activities in this step. Teacher gives students a wide chance doing observation through seeing, reading and listening, asks them to observe to the object.

b. Questioning

There were some activities doing by the student: the students are asked to ask a question related to the object they have observed, leads them in asking a questions, helps them in asking a questions. The teacher open a chance widely to the students to ask a question related to the object they have observed, Teacher guide the students to ask a question from factual to hypothetical question, teacher help the students to ask a question until they are able to ask a question individually.

\section{c. Collecting and Associating}

In associating, teacher asks the students to collect the information from any sources like reading, and doing the experiment, then the students make a conclusion based on their findings. In this activity, the students are asked by the teacher to think critically and analytically to prepare them before present their conclusion.

\section{d. Communicating}

In communicating, the teacher asks the students to tell or perform their findings in collecting and associating activity. The result of their findings will be performed in front of the class. Then, teacher assesses their performance.

3. Post-activity

In this activity, teacher and students conclude the lesson, doing an evaluation, give the feedback and result of learning, planning for remedial, enrichment programs, counseling services and / or giving assignments to both individual and group assignments according to the learning outcomes of students, and delivering learning plans for the next meeting.

Third, the thing that the teacher thinks in teaching is evaluating. To know how far students, understand what they have been taught by the teacher, the teacher need to evaluate the students. According to Trowbridge and Bybee (1990, 28-29), decision that the teachers consider in evaluating are is it important to use standardized test, How to make the accurate test?, What cognitive level to be measure?

In conclusion, the teacher need to decide the three things in their teaching they are planning the lesson plan, implementing teaching learning, and evaluating the students.

\section{METHOD}

The method used in this research was descriptive design. This research was detail of the description in implementating scientific approach in teaching English based on 2013 at SMAN 1 2x11 Kayutanam. There were two English teachers being observed. This research was used instruments of observation sheet which are used to collect the data related to implementation in using scientific approach in teaching English. Observation conducted by using observation sheet of teaching learning process done by the teachers based on the steps in scientific approach according Hosnan (2014) and Permendikbud (2013).

The data analyzed descriptively to find out the research question. To determine the quality of the data, the researcher used scale derived from Kumpulan Lembar Kerja Kurikulum 2013 with the scoring criteria: score $90<$ - $\leq 100=$ very well, $80<-\leq 90$ well, $70<-\leq 80=$ well enough, $\leq 70=$ bad.

\section{RESULT AND DISCUSSION}

The researcher did the research in SMAN $12 \times 11$ Kayutanam. There were two English teachers being observed in this research. Teacher A thought eleven grade and teacher B at twelve grade. The data of this research were collected on 5th until 19th 2019 In conducting teaching and learning process, there were three steps of activity in using scientific approach as state in kemdikbud (2013) and Hosnan (2014) that the teachers should be done in their teaching. They are pre-activity, whilst-activity (observing, questioning, experimenting, associating and communicating) and post-activity. Here, researcher came 
to the class and observed the teachers' activities during teaching learning process.

There were some steps that the teachers applied in teaching English using scientific approach: pre-activy, whilst-activity (observing, questioning, experimenting, associating, and communicating), post-activity.

The following were descriptions of the result of teaching learning process by the teachers.

a. Pre-activity.

Pre -activity is the first step in the teaching English. Here, the teachers prepare the students physically and mentally before they were active in the lesson. There were five indicators in this step that should be applied by the teacher. The teacher did not apply one of them, it means that the teachers was not success in pre-activity. Based on the two teachers, the teachers could apply this activity well. It could be seen from the percentage of the teachers were $80 \%$ (in scale $80<\mathrm{B} \leq 90$,) it was qualified by well. It means that the teachers were success in preactivity.

b. Whilst-activity

\section{Observing}

This method was one of the strategy in learning using the real object in the teaching. By using the real object, the students will explore their knowledge about things that they wanted to know. There were five activities in this step: asks students to pay attention to material given, asks students to observe the object of material, teachers ask students to analyze the object of material to find the fact, teacher leads the students to think analytically, critically and comprehensively, and the teacher asks the students to find the facts of a material.

The result of the teachers activities in this step were the teacher A almost done all the activities in observing the teacher A got $80 \%$ on each meeting. While, teacher $\mathrm{B}$ had not done the observation activity well. The teacher only got $20 \%$ in the first meeting, $40 \%$ in the second meeting and $60 \%$ in the third meeting. The total percentage of the teachers in observing step was $60 \%$. it means that the teacher was not success in this activity.

2. Questioning

In questioning step, the students are asked to make a questions to get the information that they did not know about the object given. It starts from factual until hypothetical questions. There were five activities in this step: asked the students to ask a question, motivate students to make a question, lead the students to ask a question, teacher develop students' skill in giving and answering it systematically, and teacher develop students' attitude of the tolerance and to be open to the arguments.

The result of the teachers activities in questioning was the two teachers were not applied the activities well. Teacher always skip the step in every meeting. In conclusion, the two teacher still got problems in applying this step.

Experimenting
In experimenting step, the teacher asks the student doing the experiment, they need to read from other source of books, then they are asked to observe the object and conduct the interview with interviewee. There were five steps here, Asks the students to make a group discussion, asks the students to discuss in group, teacher guided the students in doing the experiment, teacher lead the students to give their opinion, teacher supervised the students' activities during learning process to make sure all of them active in the discussion.

The result of the teachers' activities in experimenting step was different. Teacher A got $80 \%$ on each meeting and teacher B got nothing in this step. Teacher B did not apply the activities in this step. Teacher confused about how to apply this step in her teaching. In conclusion, the percentage of the teachers' activities in this step was $40 \%$ in applying the experimenting step.

3. Associating

In associating step, the students process the information they have collected in collecting information. Associating is thinking process that must be logic and systematic based on facts, it can be observed for getting the conclusion of knowledge. then they Processed the information that is collected from the nature that adds breadth and depth to the processing of information that is looking for solutions from various sources that have different opinions to the contrary. There were five activities in this step; asks students to process information they have got, asks students to find the relationship of the information with other information, asks the students to discuss the information with another group, asks students to analyze the information, asks students to add information from other sources.

Result of the teachers' activities in this step was the teacher had a problem in this step. The teachers did not know what they wanted to do in this step. Sometimes they known it but they forgot to apply it in the activity.

4. Communicating

In communicating step, the teacher asks the students to perform the results of observations, conclusions based on the results of the analysis verbally, in writing, or other media. There were some activities in this step; asks students to present their discussion, asks other students to pay attention to the group performance, asks students to make a conclusion based on their group discussion, Teacher give feedback to the work, Teacher clarify the work and add some information needed.

The result from teachers' activities in this step was the teachers also could not applied this activity in this step. Teacher A got 53\% from three meetings and the teacher B got 30\% from three meetings. The teachers were still difficult in asking the students to find out the relationship of the information, asking them to discuss with another group, and find the information from any resources. 
The problem arose because limited time they have in that step.

c. Post-activity

In post activity where teacher and students conclude the lesson. In this step, there were five activities in this step: teacher and students conclude the lesson together, teacher assesses and reflects on the activities done before, giving feedback to the learning process and results, planning an activity for remedy, planning for remedial, counselor and giving the task or homework and, Teacher tells the next material for the next meeting to students.
Based on the result from the teachers' activities, the teachers also could not apply this step well. Teacher A got $80 \%$ from three meetings and the teacher B got $40 \%$ from three meetings. Actually, the teachers known what they should do in this step. But they forgot to apply it during their teaching. Sometime the teachers done the activities but sometime no. And one more the teachers did not manage their time well. The total score of the teachers' activities in this step was $60 \%$ from all activities.

Based on the result above, it can conclude that the teachers' activities in implementing scientific approach in teaching English can be seen in the table 2 below:

Table 2. The result of teachers activities in implementing scientific approach in teaching.

\begin{tabular}{|c|c|c|c|c|c|}
\hline \multirow{2}{*}{ No } & \multirow{2}{*}{ Steps } & \multicolumn{2}{|c|}{ Teacher A } & \multicolumn{2}{c|}{ Teacher B } \\
\cline { 3 - 6 } & & Percentage & Quality & Percentage & Quality \\
\hline 1. & Pre-activity & 80 & Well & 80 & Well \\
\hline 2. & Observing & 80 & Well & 40 & Bad \\
\hline 3. & Questioning & 10 & Bad & 0 & Bad \\
\hline 4. & Experimenting & 80 & Well & 0 & Bad \\
\hline 5. & Associating & 27 & Bad & 7 & Bad \\
\hline 6. & Communicating & 53 & Bad & 20 & Bad \\
\hline 7. & Post-activity & 80 & Well & 40 & Bad \\
\hline
\end{tabular}

From the table 2 shows that the teacher A applied the pre-activity well, well in observing, also in experimenting. While in questioning bad, in associating and communicating bad. In post-activity also. The teacher B got well in pre-activity, but bad in observing, questioning, experimenting, associating, communicating and post-acvtivity. It can be concluded that, teacher have tried to applied the scientific approach in her teaching but not all from the activities run well.

\section{CONCLUSION}

Based on the findings above, it could be concluding that in the pre activity the teacher got percentage $80 \%$ of all activities. In whilst activity, there was observing, the teachers got $60 \%$ of the activities, in the questioning only got $3 \%$, because in every meeting the teacher always skip the step. Only in the first meeting one of the teacher applied this step. But, in the next meeting each of them skipped the step. While in the experimenting, the teacher got percentage of $40 \%$ of all activities in this step. In the associating, the teacher got $17 \%$ in all activities, there were some activities that the teacher skipped in associating. While in the communicating, the teacher got $37 \%$ in all activities. The teachers also skipped some activities in this step. And the last step was post activity, the teacher was got the percentage $60 \%$ of all activities. In conclusion, the percentage of activities applied by the teachers in teaching using scientific approach was got $37 \%$ Whereas the findings showed that the teachers needed to improve their ability in implementing scientific approach because it has low percentage in all steps of teaching using scientific approach based on 2013 curriculum.

\section{ACKNOWLEDGMENT}

I would like to thank people who helped and supported me in conducted this thesis. First, I wish to express my sincere gratitude to the headmaster of SMA 1 2X11 Kayu Tanam, Pariaman Regency. Furthermore, I would like to thank to my contributors: Dr. Muh. Al Hafizh. S.S. M. A and Siti Fatimah, S.S., M.Ed. who gave valuable contributions and suggestions.

\section{REFERENCES}

[1] Hosnan. 2014. Pendekatan Saintifik dan Kontekstual Dalam Pembelajaran Abad 21:Kunci Sukses Implementasi Kurikulum 2013. Bogor: Ghalia Indonesia

[2] Lazim, http://metodepembelajaran10.blogspot.com/2017/ pengertian-pendekatan-saintifik-dan.html

[3] Kumpulan Lembar Kerja Kurikulum 2013. Kemendikbud 2013

[4] Majid, A. 2013. Implementasi Kurikulum 2013. Bandung: Interest Media.

[5] Marsh, C. 1996. Handbook For Beginning Teachers. Sydney: Addison Wesley Longman Australia Pry Limited.

[6] Mulyasa, E. 2013. Pengembangan dan Implementasi Kurikulum 2013. Bandung: PT. Remaja Rosdakarya.

[7] Permendikbud. No 22 tahun 2016 tentang Standar Proses Pendidikan Dasar dan Menengah.

[8] Permendikbud. No 65 tahun 2013 tentang Standar Proses Pendididkan Dasar dan Menengah 